\title{
AN ESTIMATE OF THE ENERGY PRODUCTION POTENTIAL OF AGRICULTURAL BIOMASS IN THE LÓDŹ PROVINCE
}

\author{
POTENCJAŁ ENERGETYCZNY BIOMASY ROLNEJ \\ W WOJEWÓDZTWIE LÓDZKIM
}

\begin{abstract}
Streszczenie
Artykuł przedstawia model zagospodarowania nieużytków rolnych pod odpowiednio dobrane rośliny energetyczne. Głównym celem pracy jest szacunek potencjału energetycznego niezagospodarowanych gruntów rolnych dla województwa łódzkiego oraz określenie ceny minimalnej $1 \mathrm{GJ}$ energii pochodzącej z wybranych roślin energetycznych. Do kalkulacji ceny minimalnej wykorzystano metodę NPV, natomiast do budowy modelu zastosowano studia literaturowe. Postawiono następującą hipotezę badawczą: województwo łódzkie posiada zarówno potencjał teoretyczny, jak i ekonomiczny produkcji biomasy rolnej na nieużytkach rolnych na przykładzie wybranych roślin energetycznych. Hipoteza została zweryfikowana pozytywnie. Z przeprowadzonych badań wynika, że uprawiając wierzbę energetyczną, uzyskuje się najniższą cenę wytworzenia $1 \mathrm{MWh}$ energii.
\end{abstract}

Słowa kluczowe: biomasa rolna, rośliny energetyczne, cena minimalna, polityka energetyczno-klimatyczna

Numer klasyfikacji JEL: Q1, Q4, Q5

\section{Introduction}

Agriculture is a sector that has a significant impact on the environment and on quality of life of the population. Therefore, it is an area where it is necessary to initiate action for sustainable development. According to the 2009/28/EC Directive, Poland should achieve the level of $15 \%$ of energy being obtained from renewable resources in the total consumption in 2020. This goal will not be achieved without focusing activities on the development of dispersed energy production, including the activation of rural areas.

The aim of the study is:

- to estimate energy production potential of fallow soil and fallow land in the Łódź Province on the basis of selected energy crops,

- to calculate the minimum price of energy crops.

*Dr, Katedra Ekonomii Rozwoju, Uniwersytet Łódzki, natszub@uni.lodz.pl 
The following analysis verifies the main research hypothesis, i.e., that the Łódź Province has a theoretical and economical energy-production potential of biomass production in the areas of fallow soil and fallow land.

\section{Analysis of the area for sowing the energy crops}

According to the Agricultural Census of 2010, the number of farms in Poland stands at 2,278 thousand. The number decreased by 656 thousand farms compared to 2002 . The average size of agricultural land in a farm in the entire country is 6.82 hectares. The largest drop in the number of farms has been among the smallest ones, i.e., those up to 1 ha of arable land, and those between 1 and 5 hectares. A significant increase in the number of the largest farms (over 20 hectares) was also observed. The Łódź Province follows the national statistics. The largest part in the area structure are farms ranging from 1 to 5 hectares ( $40 \%$ of the total), followed by farms between 5 and 10 ha, as well as those under 1 ha. Figure 1 shows a summary of the structure of farms, including the area groups of agricultural land in Poland and in Polish agricultural area and the Province of Łódź.

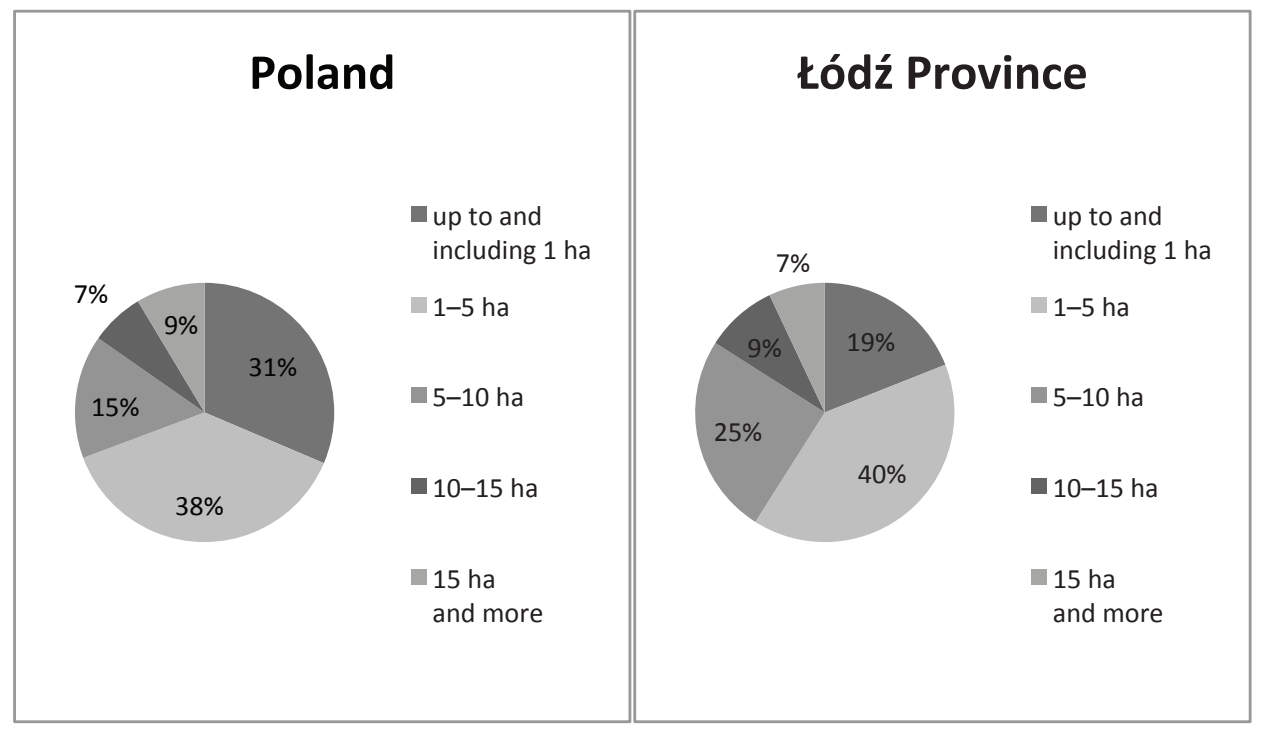

Figure 1. The structure of farms in Poland and in Lódź Province in 2010 by area groups of agricultural land

Source: own study based on the 2010 Agricultural Census, Central Statistical Office (GUS). 
The total area of agricultural land in Poland in 2010 amounted to 15,534 thousand hectares. Compared to 2002, it decreased by 1365 thousand hectares. The area of agricultural land for sowing was 10,565 thousand hectares, the area of orchards -363 thousand hectares, permanent grassland $-3,255$ thousand hectares. The share of sown area in the total of agricultural land is $68 \%$. In addition, the structure of land used for sowing was as follows: $68 \%$ of agricultural land for cultivation were grain and cereals $-7,187$ thousand ha, potatoes -387 thousand ha, sugar beets -206 thousand ha, rape (cole seed) and agrimony - 946 thousand ha, ground vegetables - 139 thousand ha. According to the Central Statistical Office (GUS) data, the structure of agricultural crops changed, compared to 2002. The area of cereal crops was reduced by $5.8 \%$, potatoes - by $3.8 \%$, sugar beet by 0.85 and ground vegetables by $0.3 \%$. However, there was a marked increase in rape (cole seed) and agrimony by $4.9 \%$ and mangold by $3.3 \%{ }^{1}$. In the Łódź Province, grains predominate $(79 \%)$ in the total sown area, followed by soilage $(8.5 \%)$, potatoes $(6.0 \%)$, industrial crops (3.3\%), edible legumes (pod vegetables) $(0.1 \%)$ and other crops $(2.9 \%)^{2}$.

The Lódź Province covers a total area of $18,219 \mathrm{~km}^{2}$. In 2011 agricultural land accounted for $87.9 \%$ of the total area. Fallow land and other undeveloped agricultural land for sowing occupy $6.6 \%$ of the total. In the region, the largest percentage of fallow and waste land is in the Bełchatów (16\%), Opoczno (12\%), Radomsko (12\%) and Pajęczno (11\%) districts. These regions are located in the southern part of the Province of Łódź. It is related to the presence of the largest open lignite quarry in Poland in the Bełchatów district. The average farm size in the Łódź Province is 7.04 ha.

It should be assumed that both in Poland and in the Łódź Province farming has a fragmented structure. Agricultural land of small area groups dominates. In the context of the use of the remnants of agricultural production for energy production, this feature has a negative effect on the development of local biomass markets. As a consequence, it is impossible to obtain potential agricultural raw materials for energy production due to the use of the remnants for own use. On the other hand, if there is surplus of production, the cost of collection and transportation of agricultural waste to decentralised centres is likely to be high. Moreover, high quality of the raw material seems unlikely to be assured due to the prolonged time of delivery to the target unit.

In order to select suitable energy crops, the agrochemical state of soil in the Łódź Province must be characterised. The study assumed that these values are the main determinant. It appears to be known that the more favourable these indices, the greater the probability of obtaining higher yield in crop production.

${ }^{1}$ GUS, Rocznik Statystyczny Rolnictwa 2010, Zakład Wydawnictw Statystycznych, Warszawa 2011, s. 2-5.

${ }^{2}$ Urząd Statystyczny w Łodzi, Rolnictwo w województwie łódzkim w 2011 r., Informacje i Opracowania Statystyczne, Łódź 2012. 


\begin{tabular}{|c|c|c|c|c|c|c|c|c|c|c|c|c|c|}
\hline & 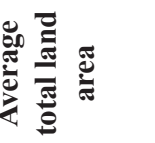 & $\underset{r}{\stackrel{\Xi}{r}}$ & $\begin{array}{l}0 \\
\text { లి }\end{array}$ & $\begin{array}{l}\infty \\
\stackrel{0}{0}\end{array}$ & $\underset{\sim}{\circ}$ & $\frac{\infty}{r}$ & $\underset{i n}{ \pm}$ & तै & $\stackrel{\overbrace{}}{r}$ & $\hat{0}$ & $\begin{array}{l}\vec{y} \\
\text { in }\end{array}$ & के & $\begin{array}{l}\text { No } \\
\text { in }\end{array}$ \\
\hline \multirow{6}{*}{ 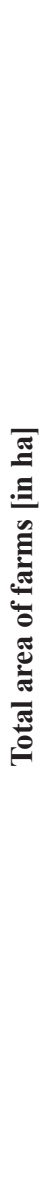 } & 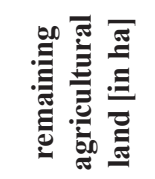 & 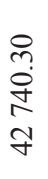 & 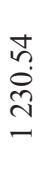 & $\begin{array}{l}2 \\
\infty \\
\infty \\
\infty \\
-1\end{array}$ & 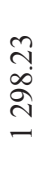 & $\begin{array}{l}\hat{n} \\
\infty \\
i n \\
n\end{array}$ & $\begin{array}{l}9 \\
\dot{0} \\
\dot{0}\end{array}$ & 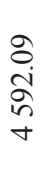 & $\begin{array}{l}\vec{a} \\
\stackrel{i}{2} \\
\stackrel{N}{n}\end{array}$ & $\begin{array}{l}\stackrel{8}{0} \\
\stackrel{+}{ \pm} \\
\text { m }\end{array}$ & $\begin{array}{l}\infty \\
\stackrel{\infty}{0} \\
m \\
m\end{array}$ & 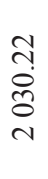 & $\begin{array}{l}\text { @ } \\
\text { J } \\
m \\
m\end{array}$ \\
\hline & 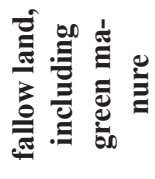 & 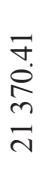 & 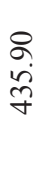 & 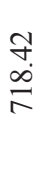 & $\frac{\infty}{\tilde{n}}$ & 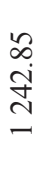 & $\begin{array}{l}\text { ळे } \\
0 \\
0 \\
0 \\
-\end{array}$ & $\begin{array}{l}n \\
\stackrel{2}{0} \\
\text { I }\end{array}$ & 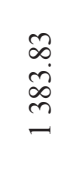 & 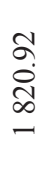 & $\begin{array}{l}\infty \\
\infty \\
\infty \\
\text { N }\end{array}$ & 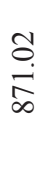 & $\begin{array}{l}\stackrel{\infty}{+} \\
\stackrel{8}{0} \\
\stackrel{2}{-1}\end{array}$ \\
\hline & 总 & 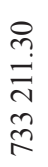 & $\begin{array}{l}\frac{\pi}{2} \\
\frac{a}{2}\end{array}$ & $\begin{array}{l}\hat{\sigma} \\
\dot{1} \\
\text { o+ } \\
\text { a }\end{array}$ & $\begin{array}{l}0 \\
\wp \\
\infty \\
\infty \\
\infty \\
n\end{array}$ & 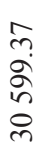 & \begin{tabular}{l}
$\hat{n}$ \\
\multirow{J}{*}{} \\
\multirow{2}{a}{}
\end{tabular} & $\begin{array}{l}\text { ते } \\
\stackrel{\sim}{1} \\
\text { ஸे } \\
\infty\end{array}$ & 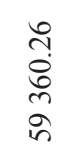 & $\begin{array}{l}\vec{a} \\
\stackrel{+}{\hat{N}} \\
\stackrel{+}{y}\end{array}$ & $\begin{array}{l}\frac{1}{3} \\
n \\
\infty \\
n \\
m\end{array}$ & 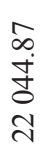 & 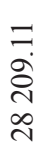 \\
\hline & 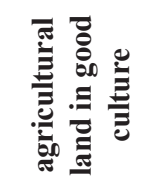 & 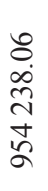 & $\begin{array}{l}\stackrel{\sim}{?} \\
\stackrel{2}{m} \\
\stackrel{2}{1}\end{array}$ & $\begin{array}{l}\hat{\sigma} \\
\dot{+} \\
\infty \\
\hat{\imath}\end{array}$ & 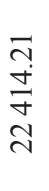 & $\begin{array}{l}\frac{m}{2} \\
\stackrel{2}{m} \\
\dot{q}\end{array}$ & $\begin{array}{l}n \\
\tilde{n} \\
\tilde{n} \\
m\end{array}$ & 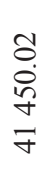 & $\frac{n}{n}$ & $\begin{array}{l}\vec{\infty} \\
\stackrel{2}{\hat{N}} \\
\hat{n}\end{array}$ & 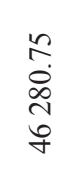 & 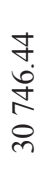 & $\begin{array}{l}m \\
n \\
\forall \\
0 \\
0 \\
n \\
n\end{array}$ \\
\hline & 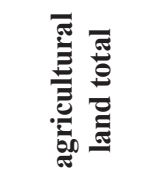 & 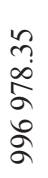 & 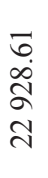 & $\begin{array}{l}0 \\
\cdots \\
n \\
0 \\
a \\
n\end{array}$ & 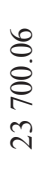 & $\begin{array}{l}\frac{8}{5} \\
\text { gิ } \\
\frac{7}{7}\end{array}$ & $\begin{array}{l}\infty \\
\tilde{n} \\
\infty \\
\infty \\
\infty \\
i n\end{array}$ & 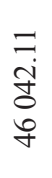 & $\frac{\hat{n}}{\stackrel{2}{\sigma}}$ & $\begin{array}{l}0 \\
\infty \\
0 \\
0 \\
0 \\
0\end{array}$ & 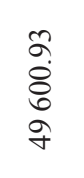 & 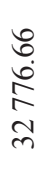 & 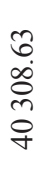 \\
\hline & & $\begin{array}{l}0 \\
0 \\
i \\
\tilde{n} \\
\tilde{n} \\
=\end{array}$ & 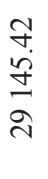 & $\begin{array}{l}n \\
\tilde{n} \\
\text { ๙ } \\
\text { ते }\end{array}$ & 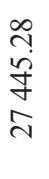 & 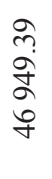 & $\begin{array}{l}\text { ठ } \\
\stackrel{2}{\alpha} \\
\stackrel{\infty}{+}\end{array}$ & $\begin{array}{l}\hat{\sigma} \\
\dot{+} \\
\text { J } \\
\hat{n}\end{array}$ & 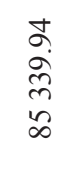 & $\begin{array}{l}\stackrel{m}{?} \\
\stackrel{\infty}{\infty} \\
\stackrel{N}{N}\end{array}$ & $\begin{array}{l}\hat{0} \\
\text { in } \\
\text { jo } \\
\text { in }\end{array}$ & 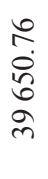 & 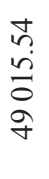 \\
\hline & 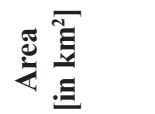 & $\begin{array}{l}\stackrel{\partial}{\sim} \\
\infty\end{array}$ & $\stackrel{\check{n}}{n}$ & $\underset{n}{8}$ & ๙ু & $\approx$ & $\underset{\circ}{\infty}$ & $\stackrel{9}{0}$ & $\stackrel{\text { ปิ }}{-}$ & $\underset{\&}{\stackrel{g}{Z}}$ & ฮิ & $\frac{\infty}{6}$ & $\underset{\infty}{+}$ \\
\hline & 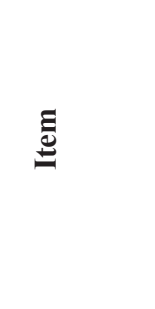 & $\begin{array}{l}\text { जే } \\
0 \\
0 \\
0 \\
0 \\
0 \\
0 \\
0\end{array}$ & 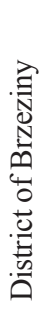 & 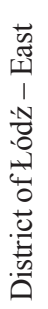 & 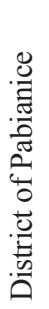 & 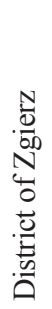 & 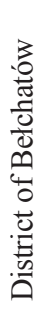 & 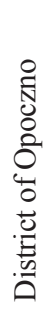 & 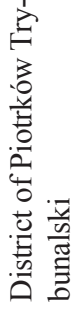 & 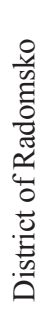 & 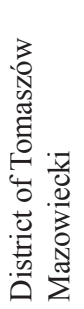 & 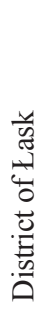 & 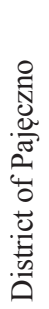 \\
\hline
\end{tabular}




\begin{tabular}{|c|c|c|c|c|c|c|c|c|c|}
\hline n̊. & $\stackrel{\overbrace{}}{?}$ & ?ु. & $\stackrel{?}{\sigma}$ & ñ & $\stackrel{尺}{\stackrel{0}{0}}$ & $\stackrel{5}{0}$ & $\begin{array}{l}\vec{b} \\
\infty\end{array}$ & $\stackrel{\infty}{\stackrel{N}{r}}$ & 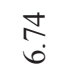 \\
\hline 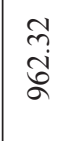 & 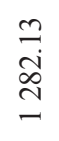 & $\begin{array}{l}8 \\
\stackrel{0}{0} \\
\text { in }\end{array}$ & $\begin{array}{l}\text { f } \\
\infty \\
0 \\
0 \\
-1\end{array}$ & 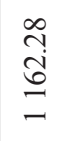 & $\frac{\vec{n}}{n}$ & $\begin{array}{l}\text { ठे. } \\
\text { ठิे }\end{array}$ & $\begin{array}{l}\vec{J} \\
\stackrel{+}{\Xi} \\
\text { J }\end{array}$ & $\begin{array}{l}\overrightarrow{0} \\
0 \\
\delta \\
0\end{array}$ & $\begin{array}{l}\vec{b} \\
\stackrel{\tilde{\sigma}}{\mathrm{\sigma}} \\
\vec{\sigma}\end{array}$ \\
\hline 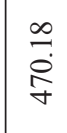 & $\begin{array}{l}\infty \\
\stackrel{2}{R} \\
\stackrel{2}{2}\end{array}$ & $\begin{array}{l}\hat{\sigma} \\
\text { in } \\
0 \\
-1\end{array}$ & 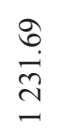 & $\begin{array}{l}\text { ț } \\
\text { : } \\
\text { in }\end{array}$ & $\begin{array}{l}a \\
0 \\
\hat{b} \\
b\end{array}$ & \begin{tabular}{l}
\multirow{J}{*}{} \\
\multirow{J}{*}{}
\end{tabular} & $\begin{array}{l}\vec{\sigma} \\
\widetilde{1} \\
\infty\end{array}$ & 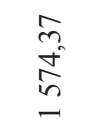 & $\begin{array}{l}\text { w } \\
0 \\
0 \\
0 \\
0\end{array}$ \\
\hline $\begin{array}{l}\frac{0}{2} \\
\stackrel{2}{m} \\
\text { m. }\end{array}$ & 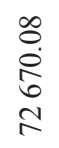 & 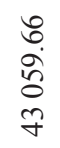 & 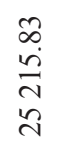 & 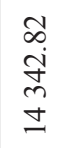 & $\begin{array}{l}= \\
\text { in } \\
\text { in }\end{array}$ & \begin{tabular}{l}
$n$ \\
$\hat{D}$ \\
$\infty$ \\
\multirow{7}{*}{}
\end{tabular} & 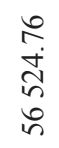 & $\begin{array}{l}\hat{\theta} \\
\dot{0} \\
\stackrel{8}{9}\end{array}$ & $\begin{array}{l}\vec{n} \\
\tilde{\sigma} \\
\vec{\sigma} \\
\tilde{n}\end{array}$ \\
\hline $\begin{array}{l}\hat{N} \\
\text { 它 } \\
\text { 品 }\end{array}$ & $\begin{array}{l}\vec{R} \\
\infty \\
\infty \\
\infty \\
\infty\end{array}$ & $\begin{array}{l}0 \\
m \\
\infty \\
0 \\
0 \\
\vec{n}\end{array}$ & $\begin{array}{l}\stackrel{+}{n} \\
\stackrel{2}{\$} \\
0 \\
0\end{array}$ & 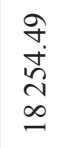 & 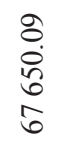 & $\begin{array}{l}\vec{\sigma} \\
b \\
\check{\gamma} \\
\text { on }\end{array}$ & $\begin{array}{l}0 \\
\stackrel{0}{0} \\
\stackrel{0}{0} \\
\stackrel{2}{R}\end{array}$ & 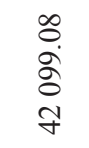 & 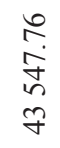 \\
\hline $\begin{array}{l}\text { to } \\
\text { i. } \\
\infty \\
n \\
n \\
i n\end{array}$ & $\begin{array}{l}n \\
\infty \\
\stackrel{0}{0} \\
\delta \\
\&\end{array}$ & 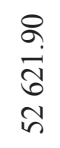 & 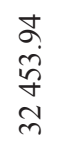 & 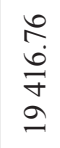 & $\begin{array}{l}8 \\
\tilde{\Xi} \\
\tilde{\delta} \\
\infty\end{array}$ & $\begin{array}{l}\text { ठ } \\
\dot{0} \\
8 \\
0 \\
0\end{array}$ & $\begin{array}{l}\infty \\
\infty \\
\tilde{f} \\
\stackrel{n}{N} \\
\stackrel{N}{n}\end{array}$ & $\begin{array}{l}\stackrel{0}{1} \\
\dot{d} \\
\tilde{\gamma}\end{array}$ & $\begin{array}{l}\hat{n} \\
\tilde{\infty} \\
\infty \\
\dot{\sigma} \\
\tilde{\gamma}\end{array}$ \\
\hline $\begin{array}{l}\hat{\sim} \\
\infty \\
\infty \\
\sim \\
\widetilde{\sigma}\end{array}$ & $\begin{array}{l}\infty \\
\infty \\
\infty \\
\infty \\
0 \\
0\end{array}$ & 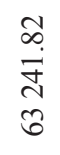 & $\begin{array}{l}\hat{n} \\
\hat{a} \\
\hat{\alpha} \\
\text { on }\end{array}$ & $\begin{array}{l}\overrightarrow{0} \\
\dot{d} \\
\tilde{n} \\
\tilde{d}\end{array}$ & 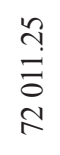 & 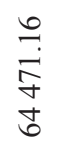 & $\begin{array}{l}\underset{+}{\Xi} \\
\stackrel{\infty}{\Xi} \\
\vec{a}\end{array}$ & 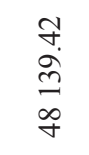 & 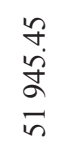 \\
\hline $\begin{array}{l}\vec{\infty} \\
\infty\end{array}$ & $\bar{g}$ & 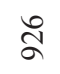 & in & : & $\underset{\infty}{\infty}$ & $\stackrel{\Re}{\vDash}$ & $\stackrel{\infty}{\infty}$ & \& & $\approx n$ \\
\hline 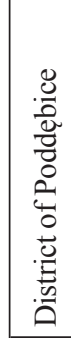 & 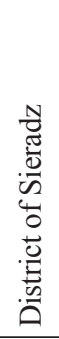 & 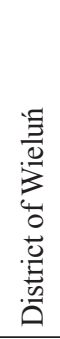 & 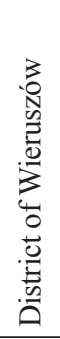 & 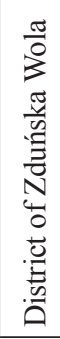 & 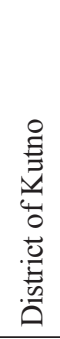 & 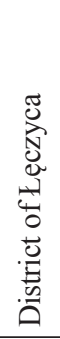 & 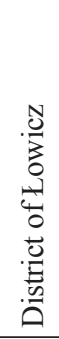 & 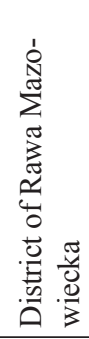 & 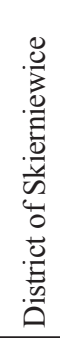 \\
\hline
\end{tabular}


The main indicators of soil fertility include: the $\mathrm{pH}$, the amount of assimilable forms of nitrogen, potassium, magnesium, phosphorus, mineral content, quality and abundance of groundwater. Soil fertility is formed naturally in the soil-forming processes. It is possible to increase fertility through the use of appropriate types and doses of fertilisers. Land productivity is defined as the quantity of plant biomass production ${ }^{3}$.

According to studies by IUNG (National Institute of Crop Science and Plant Cultivation in Puławy), nearly $70 \%$ of soils in the Łódź Province are highly acidic or acidic. This index is the highest, compared to other regions of Poland. The $\mathrm{pH}$ of the soil affects the plants' ability to absorb nutrients. More than $50 \%$ of soils require liming. Soils with $\mathrm{pH}<5$ have the ability to collect heavy metals easier. The region's share of soil with low and very low average content of $\mathrm{N}_{\text {min }}$ (mineral nitrogen) in the spring is at a level of 20-30\%. Nitrogen is an essential crop-producing component. On average, $20-40 \%$ of soils in the Łódź Province have low phosphorus content, and nearly $80 \%$ of soils have low and very low potassium contents. However, $50 \%$ of the soil is characterised by low and very low magnesium content ${ }^{4}$.

About $16.4 \%$ of agricultural land in the Łódź Province is at risk of surface erosion $^{5}$. This share is not the worst in the country, because the region is in eleventh place out of sixteen regions.

The research by J. Igras and W. Lipiński indicates that the Lódź province, together with the świętokrzyskie, mazowieckie, podlaskie and lubuskie provinces, is classified as a fourth region on a scale of 1 to 4 . This region is characterised by the lowest intensity of crop production, the worst soils, low levels of fertilisation, particularly with calcium components, and the worst indicators of soil quality ${ }^{6}$.

The soils that predominate in the region are of the IV, V and VI valuation class $(80 \%$ of the total). Figure 2 shows the structure of soil by valuation class.

${ }^{3}$ K. Filipiak, Syntetyczny wskaźnik żyzności gleby, [w:] M. Fotyma [red.], Nawozy i nawożenie, Polskie Towarzystwo Nawozowe, Instytut Upraw, Nawożenia i Gleboznawstwa, Puławy 2010, s. 7,8 .

${ }^{4}$ J. Igras, W. Lipiński, Ocena wybranych elementów stanu żyzności gleby i jakości płytkich wód gruntowych na tle intensywności produkcji roślinnej w ujęciu regionalnym, „Pamiętnik Puławski” 2006, z. 142, s. 71-79.

${ }^{5}$ S. Krasowicz, W. Oleszek, J. Horabik, R. Dębicki, J. Jankowiak, T. Stuczyński, J. Jadczyszyn, Racjonalne gospodarowanie środowiskiem glebowym Polski, "Polish Journal of Agronomy" 2011, no. 7, s. $43-58$.

${ }^{6}$ J. Igras, W. Lipiński, Regionalne zróżnicowanie stanu agrochemicznego gleb $w$ Polsce, [w:] A. Harasim (red.), Regionalne zróżnicowanie produkcji rolniczej w Polsce, Raporty PIB 3, z. 3, Instytut Upraw, Nawożenia i Gleboznawstwa, Państwowy Instytut Badawczy, Puławy 2006, s. 147-162. 


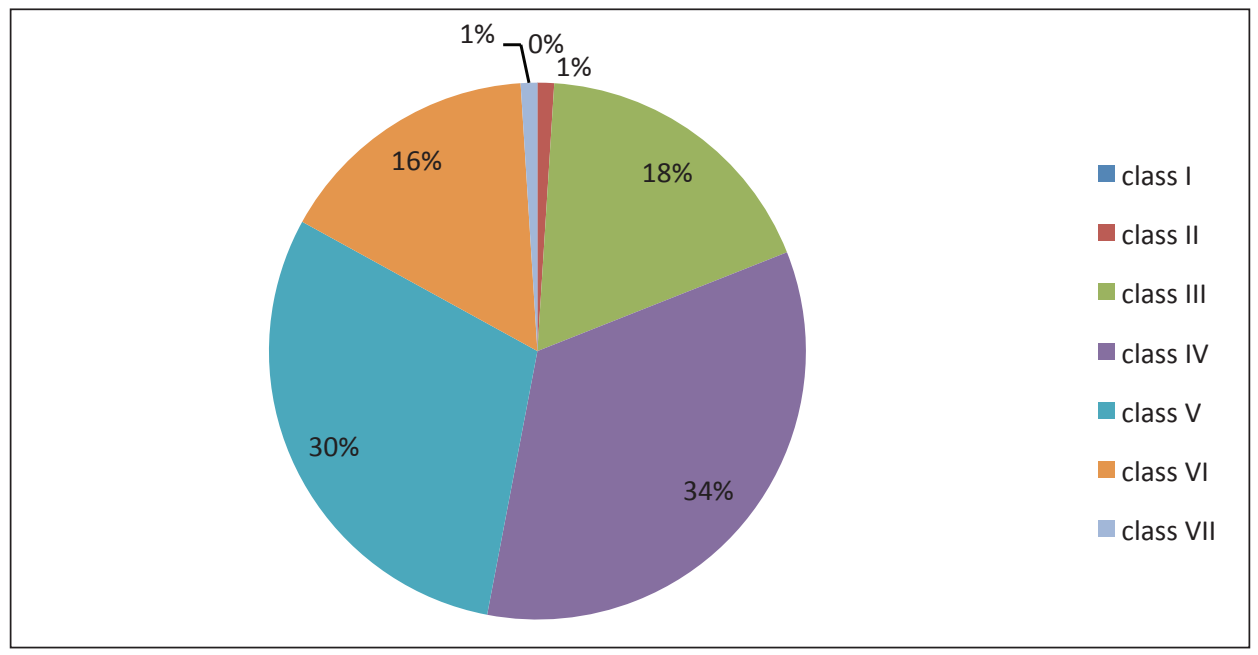

Figure 2. Structure of soils by valuation classes in the Kódź Province

Source: own study based on CSO (GUS), “Statistical Yearbook of Agriculture 2010”, Zaktad Wydawnictw Statystycznych, Warszawa 2011.

According to research by the European Regional Centre for Ecohydrology (Europejskie Regionalne Centrum Ekohydrologii) the problems associated with scarcity and poor quality of water are common in Poland in general, as well as in the Lódź Province. There is a noticeable reduction of water level in lakes, reservoirs and in the ground. Climate changes, the gradually increasing average air temperature affects the deterioration of retention capacity water resources and the drying of the outer layer of the soil ${ }^{7}$. As a consequence of that, agricultural productivity will reduce, the quality of agricultural products will deteriorate, the supply of agricultural products will reduce, prices will rise and the public health will deteriorate.

\section{Selection of plants for energy production}

It has been assumed that in the model, fallow land and waste land in the Łódź Province, as well as river basins, had been allocated for energy crops. The choice has been made from the following energy crops grown in Poland:

- Osier (Salix viminalis),

- Virginia mallow (Sida hermaphrodita),

- Multiflora rose/baby rose (Rosa multiflora),

${ }^{7}$ Z. W. Kundzewicz, M. Zalewski, A. Kędziora, E. Pierzgalski, Zagrożenia związane z woda, „Nauka” 2010, nr 4, s. 87-96. 
- Giant miscanthus/elephant grass/chinese silver grass (Miscanthus sinensis gigantea),

- Sugar miscanthus (Miscanthus sacchariflorus),

- Switchgrass (Panicum virgatum),

- Prairie tallgrass/Big bluestem (Andropogon gerardi) ${ }^{8}$.

The agro-chemical conditions of the region, presented above, indicate that it is necessary to choose a little-demanding plant in terms of cultivation requirements. The choice should be made between osier, miscanthus and Virginia mallow. Other plants were eliminated from further consideration due to:

- susceptibility to weed - Prairie tallgrass';

- energy-intensive production and inefficiency in the production of alcohol - switchgrass $^{10}$;

- high water content at the time of the final harvest - multiflora rose ${ }^{11}$.

The reasons for the choice of other energy crops were the following.

Miscanthus has a $\mathrm{C}_{4}$ photosynthetic pathway, which allows efficient use of water and minerals and efficient use of solar radiation. The negative feature of this plant is that the reproduction, in the Polish climatic conditions, can only be vegetative. In the conditions of the habitat it does not produce fertile seeds. Miscanthus is also susceptible to freezing ${ }^{12}$. However, it seems that this plant has the potential for further development for energy purposes. Miscanthus prefers class IV and V soils. It has lower water and soil requirements than osier ${ }^{13}$.

Virginia mallow can give crop on arid lands. It is compared to osier. The problem is the low germination rate of seeds (often $30-50 \%)^{14}$.

Osier requires class III-IV soil with relatively high humidity. It has a large potential for biomass production and is suitable for energy-production and industrial

${ }^{8}$ A. Zawadzka, M. Imbierowicz, Rośliny energetyczne oraz technologie i urzadzenia dla przetwórni biomasy, [w:] E. Kochańska (red.), Inwestowanie w energetykę odnawialna. Aspekty ekologiczne, technologie, finansowanie i benchmarking, Stowarzyszenie Doradców Gospodarczych Pro-Akademia, Łódź 2010, s. 169, 170.

${ }^{9}$ W. Budzyński, S. Bielski, Surowce energetyczne pochodzenia rolniczego. Cz. II: Biomasa jako paliwo stałe (artykut przegladowy), „Acta Sci. Pol. Agricultura” 2004, nr 3(2), s. 19.

10 Tamże, s. 174, 175.

${ }^{11}$ D. Chołuj, S. Podlaski, G. Wiśniewski, J. Szmalec, Kompleksowa ocena biologicznej przydatności 7 gatunków roślin wykorzystywanych na cele energetyczne, [w:] A. Harasim [red.], Uprawa roślin energetycznych a wykorzystanie rolniczej przestrzeni produkcyjnej w Polsce, Instytut Uprawy, Nawożenia i Gleboznawstwa PIB, „Studia i Raporty” 2008, z. 11, Puławy, s. 81-99.

${ }_{12}$ M. Matyka, J. Kuś, Plonowanie i cechy biometryczne wybranych genotypów miskanta, „Problemy Inżynierii Rolniczej” 2011, nr 2, s. 157, 158.

13 J. Kolowca, M. Wróbel, Wpływ wilgotności na właściwości reologiczne rozdrobnionej trawy energetycznej Miscanthus Giganteus, „Inżynieria Rolnicza” 2010, nr 4(122), s. 115, 116.

${ }^{14}$ M. Grzesik, R. Janas, Z. Romanowska-Duda, Stymulacja wzrostu i procesów metabolicznych ślazowca pensylwańskiego (Sida hermaphrodita L. Rusby) za pomoca hydrokondycjonowania nasion, „Problemy Inżynierii Rolniczej” 2011, nr 4, s. 81, 82. 
use $^{15}$. In practice, it is harvested manually on small plantations. In the case of large plantations, machine harvesting is used. The main disadvantage of this type of harvesting is the high cost of harvesting machines ${ }^{16}$. The amount of crop obtained depends on many factors such as: soil type and humidity, fertilizing, seedling quality, accuracy of soil preparation for planting, etc. In practice, osier is harvested every year, every two or every three years, the latter being the most efficient from the perspective of energy yield and energy-intensiveness. Large woody biomass growth is observed in that case. The useful life of the plantation is $25-30$ years ${ }^{17}$.

Theoretical assumptions for the calculation of minimum prices of energy obtained from energy crops

The cost calculation (table 2) was based on research by IUNG, with inflation rate taken into account. The calculation included the preparation of the field, the purchase cost of seedlings, the annual cost of care, fertiliser and remuneration for labour. In addition, the cost of machine harvesting ${ }^{18}$ was taken into account.

Table 2. Cost of setting up plantations of selected species of energy crops (prices as of the first quarter of 2009)

\begin{tabular}{|c|c|c|c|c|c|}
\hline \multirow{2}{*}{\multicolumn{2}{|c|}{$\begin{array}{c}\text { Species } \\
\text { Reproduction material }\end{array}$}} & \multirow{2}{*}{$\begin{array}{c}\text { Osier } \\
\text { cuttings }\end{array}$} & \multirow{2}{*}{$\begin{array}{c}\text { Miscanthus } \\
\text { seedlings } \\
\end{array}$} & \multicolumn{2}{|c|}{ Virginia mallow } \\
\hline & & & & seeds & seedlings \\
\hline \multirow{4}{*}{$\begin{array}{l}\text { Preparation of the } \\
\text { field }\end{array}$} & soil testing & \multicolumn{4}{|c|}{20} \\
\hline & use of machines & \multicolumn{2}{|r|}{941} & 871 & 941 \\
\hline & fertilisers, herbicides & \multicolumn{2}{|r|}{832} & 729 & 832 \\
\hline & remuneration & \multicolumn{2}{|r|}{97} & 54 & 97 \\
\hline \multicolumn{2}{|c|}{ Cost of purchase (growing a seedling) } & 1800 & 16250 & 3000 & 3000 \\
\hline \multirow[t]{2}{*}{ Cost of planting } & use of machines & 60 & 60 & 120 & 60 \\
\hline & remuneration & 1156 & 1123 & 76 & 1728 \\
\hline \multirow{3}{*}{$\begin{array}{l}\text { Cost of care (first } \\
\text { year of vegetation) }\end{array}$} & use of machines & 340 & 200 & & 340 \\
\hline & fertilisers, pesticides & 545 & 267 & 545 & 545 \\
\hline & remuneration & & & & 3564 \\
\hline \multicolumn{2}{|c|}{$\begin{array}{l}\text { Total cost of setting up a plantation in } \\
\text { PLN/ha/year }\end{array}$} & 9355 & 2354 & 9319 & 11127 \\
\hline
\end{tabular}

Source: IUNG-PIB Puławy, [w:] H. Skórnicki (red.), Skrócone normatywy produkcji rolnej, Wydawnictwo Ministerstwa Rolnictwa i Rozwoju Wsi, Radom 2010, s. 32.

15 Tamże, s. 169, 170.

${ }^{16}$ D. Kwaśniewski, K. Mudryk, M. Wróbel, Zbiór wierzby energetycznej z użyciem piły łańcuchowej, „Inżynieria Rolnicza” 2006, nr 13, s. 271, 272.

17 D. Baran, D. Kwaśniewski, K. Mudryk, Wybrane właściwości fizyczne trzyletniej wierzby energetycznej, „Inżynieria Rolnicza” 2007, nr 8(96), s. 7.

18 A. Lisowski (red.), Technologie zbioru roślin energetycznych, Wydawnictwo SGGW, Warszawa 2010, s. 126-132. 
The Net Present Value (NPV) method was used to calculate the minimum price. The following formula is used:

\section{Formula 1}

$$
N P V=\sum_{t=0} C F_{t} \times D F_{t}
$$

where:

$C F_{t}$ - Cash Flow of years).

$D F_{t}-$ discount factor $\left(D F=\frac{1}{(1+r)^{n}}\right.$; where $r$-discount rate, $n-$ the number

It has been assumed that the minimum price ${ }^{19}$ for energy obtained from energy plantations was established for $N P V=0$. Determining the appropriate discount rate was a problematic issue. The project to adapt fallow land for growing energy crops does not have a clearly defined subject to real property ownership rights. Therefore, this paper presents the prices of biomass for the individual energy crops, taking into account the social discount rate (SDR) of 5.5\% as recommended by the European Commission ${ }^{20}$, the discount rate of $3 \%$ as recommended by the $\mathrm{EPA}^{21}$ and the discount rate of $7.796 \%$ as set by the President of the Energy Regulatory Office (URE) in 2012 as the weighted average cost of capital after tax ${ }^{22}$.

It should be noted that the calculated minimum price for each energy crop was determined from the perspective of the use of fallow and waste land in the Łódź Province. The analysis does not take into account the cost of transportation and processing of biomass. This is due to the fact that the research of the convenient location of distributed units is in progress.

\section{Analysis of energy potential of the selected energy plants}

Considering the agrochemical conditions of the Łódź Region, the analysis assumed planting miscanthus and Virginia mallow (Sida) on fallow land, and planting osier along river beds. The model assumed the need to incorporate best

${ }^{19}$ K. Havlíčková, J. Weger, J. Knápek, Modeling of biomass prices for bio-energy market in the Czech Republic, "Stimulation Modelling Practice and Theory" 2011, no. 19, s. 1946-1956.

${ }^{20}$ Komisja Europejska, Dyrekcja Generalna ds. Polityki Regionalnej, Przewodnik do analizy kosztów i korzyści projektów inwestycyjnych. Fundusze strukturalne, Fundusz Spójności oraz Instrument Przedakcesyjny, Final Report 2008, s. 62.

${ }^{21}$ M. Ligus, Efektywność inwestycji w odnawialne źródta energii. Analiza kosztów i korzyści, CeDeWu Sp. z o.o., Warszawa 2012, s. 59.

${ }^{22}$ Urząd Regulacji Energetyki, Departament Taryf, Taryfy OSD na rok 2012 (dotyczy OSD, którzy dokonali z dniem 1 lipca 2007 r. rozdzielenia działalności), Warszawa, listopad 2011, s. 11. 
practices as far as water management is concerned. Osier is grown perennially. There is a concern that in the long run, if osier is planted on fallow land, it will adversely affect the water balance of the area.

The values presented in table 3 were used to estimate the energy-production potential of the crops.

Table 3. Dry matter yield and calorific value of selected energy crops

\begin{tabular}{|l|c|c|c|c|c|}
\hline \multirow{2}{*}{ Feature } & \multirow{2}{*}{$\begin{array}{c}\text { Virginia mallow } \\
\text { (Sida herma- } \\
\text { phrodita) }\end{array}$} & Miscanthus & \multicolumn{3}{|c|}{ Osier (Salix viminalis) } \\
\cline { 4 - 6 } & 10.7 & 17.7 & 14.8 & 16.1 & 21.5 \\
\hline $\begin{array}{l}\text { Dry matter } \\
\text { yield [t/ha] }\end{array}$ & 17.4 & 17.3 & 18.56 & 19.25 & 19.56 \\
\hline $\begin{array}{l}\text { Calorific value } \\
\text { [GJ/ha] }\end{array}$ & year & $\begin{array}{c}\text { harvest every } \\
\text { two years }\end{array}$ & $\begin{array}{c}\text { harvest every } \\
\text { three years }\end{array}$ \\
\hline
\end{tabular}

Source: own research, based on W. Budzyński, S. Bielski, Surowce energetyczne pochodzenia rolniczego. Cz. II: Biomasa jako paliwo state (artykut przegladowy), "Acta Sci. Pol. Agricultura" 2004, no. 3(2); J. Kuś, A. Faber, M. Stasiak, A. Kawalec, Plonowanie wybranych gatunków roślin uprawianych na cele energetyczne na różnych glebach, „Problemy Inżynierii Rolniczej” 2008, no. 1; M. Matyka, J. Kuś, Plonowanie i cechy biometryczne wybranych genotypów miskanta, " Problemy Inżynierii Rolniczej” 2011, no. 2; T. Piskier, Potencjat energetyczny topinamburu, „Problemy Inżynierii Rolniczej" 2009, no. 1.

The main rivers in the Province are the Bzura, Pilica and Warta. The length of rivers in the Łódź Province is estimated to be about $1300 \mathrm{~km}$. It has been assumed that osier will be planted along the river beds on both sides of the river, in a 5-metre wide belt (the average length of an arm of harvesting equipment has been taken into account to minimize energy consumption in production). In addition, it has been taken into account that osier will be planted along $50 \%$ of the length of the rivers (areas protected by law must be concerned). The total area of the plantations is $650 \mathrm{ha}$. Assuming a short-cycle harvest, the dry matter yield is theoretically assumed at 9,620 tonnes, which gives 178,547.2 GJ of obtainable energy. However, if a harvest every two years is assumed, the dry matter yield is 10,465 tonnes, which can produce $201,451.25$ GJ of energy. In the case of a harvest every three years, the dry matter yield is 13,975 tonnes, which gives 273,351 GJ of energy. The results of the estimate of energy potential for the other energy crops are presented in table 4 . 
Table 4. Estimated energy-production potential of selected plants in the districts of the Lódź Province

\begin{tabular}{|c|c|c|c|c|c|}
\hline \multirow{3}{*}{ Item } & \multirow{3}{*}{$\begin{array}{c}\text { Area for } \\
\text { sowing } \\
\text { [in ha] }\end{array}$} & \multicolumn{4}{|c|}{ Theoretical potential } \\
\hline & & \multicolumn{2}{|c|}{$\begin{array}{c}\text { Virginia mallow } \\
\text { (Sida hermaphrodita) }\end{array}$} & \multicolumn{2}{|c|}{ miscanthus } \\
\hline & & $\begin{array}{c}\text { Dry matter } \\
\text { yield [t/year] }\end{array}$ & $\begin{array}{c}\text { Energy yield } \\
\text { [TJ/t] of dry } \\
\text { matter }\end{array}$ & $\begin{array}{c}\text { Dry mat- } \\
\text { ter yield } \\
\text { [t/year] }\end{array}$ & $\begin{array}{c}\text { Energy yield } \\
\text { [TJ/t] of dry } \\
\text { matter }\end{array}$ \\
\hline Łódź Province & 64110.71 & 685984.60 & 11935.9 & 1134760.00 & 19630.9 \\
\hline District of Łódź - East & 1948.96 & 20853.87 & 362.8 & 34496.59 & 596.8 \\
\hline District of Pabianice & 1937.68 & 20733.18 & 360.8 & 34296.94 & 593.3 \\
\hline District of Zgierz & 2541.08 & 27189.56 & 473.1 & 44977.12 & 778.1 \\
\hline District of Brzeziny & 994.17 & 10637.62 & 185.1 & 17596.81 & 304.4 \\
\hline District of Bełchatów & 5704.08 & 61033.66 & 1062.0 & 100962.20 & 1746.6 \\
\hline District of Opoczno & 5712.24 & 61120.97 & 1063.5 & 101106.60 & 1749.1 \\
\hline $\begin{array}{l}\text { District of Piotrków } \\
\text { Trybunalski }\end{array}$ & 4115.84 & 44039.49 & 766.3 & 72850.37 & 1260.3 \\
\hline District of Radomsko & 8194.98 & 87686.29 & 1525.7 & 145051.10 & 2509.4 \\
\hline $\begin{array}{l}\text { District of Tomaszów } \\
\text { Mazowiecki }\end{array}$ & 4609.99 & 49326.89 & 858.3 & 81596.82 & 1411.6 \\
\hline District of Łask & 2901.24 & 31043.27 & 540.1 & 51351.95 & 888.4 \\
\hline District of Pajęczno & 4604.78 & 49271.15 & 857.3 & 81504.61 & 1410.0 \\
\hline District of Poddębice & 1432.50 & 15327.75 & 266.7 & 25355.25 & 438.6 \\
\hline District of Sieradz & 1984.71 & 21236.4 & 369.5 & 35129.37 & 607.7 \\
\hline District of Wieluń & 2608.69 & 27912.98 & 485.7 & 46173.81 & 798.8 \\
\hline District of Wieruszów & 2915.09 & 31191.46 & 542.7 & 51597.09 & 892.6 \\
\hline District of Zduńska Wola & 1728.92 & 18499.44 & 321.9 & 30601.88 & 529.4 \\
\hline District of Kutno & 1029.40 & 11014.58 & 191.6 & 18220.38 & 315.2 \\
\hline District of Łęczyca & 1102.03 & 11791.72 & 205.2 & 19505.93 & 337.4 \\
\hline District of Łowicz & 2001.02 & 21410.91 & 372.5 & 35418.05 & 612.7 \\
\hline $\begin{array}{l}\text { District of Rawa Ma- } \\
\text { zowiecka }\end{array}$ & 2639.38 & 28241.37 & 491.4 & 46717.03 & 808.2 \\
\hline District of Skierniewice & 3403.93 & 36422.05 & 633.7 & 60249.56 & 1042.3 \\
\hline
\end{tabular}

Source: own study. 
Altogether, the development of fallow land in the Łódź Region can theoretically yield 11.9 PJ of energy from Virginia mallow (Sida) and 19.6 PJ of energy from miscanthus. The District of Radomsko is the area with the highest potential for energy yield from both the plants. However, the highest energy-production potential of Virginia mallow (Sida) is noted in the District of Opoczno.

\section{Profitability analysis of energy production from selected energy crops}

The cost of biomass production from energy crops was calculated in the short term and in the long term perspective. The short-term perspective took into account, in the case of miscanthus and Virginia mallow, the costs until the first harvest, that is, in the second year since setting up of the plantation. In the case of osier, the costs were estimated for the first harvest after a year, after two and after three years.

The long-term perspective took into account the possibly shortest time of existence of perennial plantations. A period of 15 years was adopted for miscanthus and Virginia mallow (Sida), and a period of 20 years was adopted for osier.

The cost of preparation of land for agricultural biomass production, from the perspective of the entire Łódź Region, differed depending on the plant. It seems obvious that the development of river beds for growing osier is the least expensive, if only because of the area of the developed land. The cost of setting up an osier plantation was estimated at 6.11 million PLN. The total cost of harvest was 617 thousand PLN on the average. However, the annual cost of care in later years was assumed at 2.9 million PLN.

The cost of planting Virginia mallow (sida) was estimated separately for seeds and seedlings. The total cost of setting up plantations from the perspective of the entire Łódź Region was estimated at: for seeds -600.5 million PLN and for the seedlings - 717 million PLN. The estimated cost of the harvest for seeds and seedlings amounted to 60.9 million PLN. The cost of care in the long term amounted to 286.6 million PLN.

The cost of setting up a miscanthus plantation is higher than for Virginia mallow (Sida) and amounts to 1.5 thousand million PLN. The total cost of harvest was assumed to be at the same level as in the case of Virginia mallow (Sida). However, the annual cost of care amounted to 259.7 million PLN. It is lower than in the case of Virginia mallow by 26.9 million PLN.

The analysis of the data indicates that in the short term perspective, i.e., when setting the price for NPV $=0$ during the first harvest, the price levels are similar for miscanthus and Virginia mallow and osier with annual harvest. A substantial reduction of prices for osier harvested every two and three years is noticeable. 
In the long term perspective the prices are the lowest for osier. The price is quite significantly different for Virginia mallow (sida). This is due to the fact that the seeds have a low germination rate. Despite the difficulties related to reproduction of miscanthus in the Polish climatic conditions, this plant seems to be competitive with osier.

Table 5. Summary of minimum prices for plantations of selected energy crops

\begin{tabular}{|l|c|c|c|c|c|c|}
\hline \multirow{2}{*}{\begin{tabular}{c}
\multirow{2}{*}{$\begin{array}{c}\text { Plantation } \\
\text { duration }\end{array}$} \\
\cline { 2 - 7 }
\end{tabular}} & \multirow{2}{*}{ miscanthus } & Virginia mallow & \multicolumn{2}{c|}{ osier } \\
\cline { 2 - 6 } & seeds & seedlings & $\begin{array}{c}\text { Minimum price [PLN/GJ] } \\
\text { harvest } \\
\text { each year } \\
\text { harvest } \\
\text { every two } \\
\text { years }\end{array}$ & $\begin{array}{c}\text { harvest } \\
\text { every } \\
\text { three } \\
\text { years }\end{array}$ \\
\hline $\begin{array}{l}\text { Short-term per- } \\
\text { spective (7.796\% } \\
\text { discount) }\end{array}$ & 54.49 & 52.57 & 57.63 & 53.96 & 31.63 & 19.35 \\
\hline $\begin{array}{l}\text { Short-term perspec- } \\
\text { tive (5.5\% discount) }\end{array}$ & 57.53 & 52.32 & 57.33 & 53.96 & 31.49 & 19.20 \\
\hline $\begin{array}{l}\text { Short-term perspec- } \\
\text { tive (3\% discount) }\end{array}$ & 53.65 & 52.05 & 57.00 & 53.96 & 31.32 & 19.03 \\
\hline $\begin{array}{l}\text { Long-term per- } \\
\text { spective (discount } \\
7.796 \%)\end{array}$ & 25.13 & 34.00 & 35.06 & 22.93 & 18.73 & 13.37 \\
\hline $\begin{array}{l}\text { Long-term perspec- } \\
\text { tive (5.5\% discount) }\end{array}$ & 23.28 & 33.39 & 34.31 & 22.45 & 18.32 & 13.07 \\
\hline $\begin{array}{l}\text { Long-term perspec- } \\
\text { tive (3\% discount) }\end{array}$ & 22.31 & 32.79 & 33.59 & 21.97 & 17.91 & 12.77 \\
\hline
\end{tabular}

Source: own study.

According to the Energy Regulatory Office (URE) there is one biogas plant in the Łódź Province, which produces energy from agricultural biomass, with a total installed capacity of $1.998 \mathrm{MW}$. Wind power systems dominate, with a total capacity of $216.365 \mathrm{MW}$.

The heat price in 2011 in Łódź Province determined by the weighted average method was 39.51 PLN/GJ (using the median of $44.60 \mathrm{PLN} / \mathrm{GJ}$ ) and in 2012 - 39.93 PLN/GJ. The electricity price in 2012 was $227.68 \mathrm{PLN} / \mathrm{MWh}^{23}$. The

${ }^{23}$ GUS (Central Statistical Office), Gospodarka paliwowo-energetyczna w latach 2010, 2011, Warszawa 2012, s. 234-237; GUS (Central Statistical Office), Gospodarka paliwowo-energetyczna w latach 2011, 2012, Warszawa 2013, s. 235. 
monthly reports ${ }^{24}$ published by the Polish Power Exchange (TGE) indicate that in 2012, in the months from January to October, the weekly average-weighted price oscillated around $180 \mathrm{PLN} / \mathrm{MWh}$. According to the economic analysis of energy crops, the price per MWh for Sida (Virginia mallow) is at the level of PLN 126.21 to 120.91 depending on the assumed discount rate in the long term. In comparison, this price range for miscanthus is from 90.46 to $80.33 \mathrm{PLN}$, while the price for the osier is from $82 \mathrm{PLN} / \mathrm{MWh}$ to $46 \mathrm{PLN} / \mathrm{MWh}$.

The total electricity consumption in the Łódź Province in 2011 was $11,751 \mathrm{GWh}$, which is nearly $8 \%$ of energy consumed in the country. Moreover, the total consumption in the Łódź Province in 2012 was $11,035 \mathrm{GWh}$ which is $7.5 \%$ of energy consumed in the country. The theoretical potential of energy crops (taking into account the average energy value for osier harvested every year, every two or every three years) stands at: osier and miscanthus $-19,848.68 \mathrm{TJ}$ and osier and sida $-12,153.68 \mathrm{TJ}$. These values are, respectively, for a mix with miscanthus $-47 \%$, and for a mix with sida $-29 \%$ of the total electricity consumed in the Łódź Province.

\section{Discussion}

The term biomass include a lot of energy carrier. This is what the final product will become the processed biomass depends on: available substrate, technology and investment capacity. According to the European Parliament and Council 2009/28/EC Directive of 23 April 2009, biomass is the part of products, waste and biological residues from agriculture (including vegetal and animal substances), forestry, industry including the fisheries and aquaculture as well as the biodegradable fraction of industrial and municipal waste.

Distinguished biomass from energy crops and by-products, i.e. the forestry industry and agriculture, nurturing of parks and gardens, food waste and the paper industry ${ }^{25}$. The chemical energy of biomass by different conversion methods is transformation into heat, electricity and transport fuel. The carbon dioxide is byproduct of the chemical energy conversion. It is assumed that the carbon dioxide balance is zero because of the closed circuit - the amount of carbon dioxide in the transforming process to the final energy is equal the amount absorbed by the plant as a result of photosynthesis ${ }^{26}$. Biomass is the raw material for the production of

${ }^{24}$ Towarowa Giełda Energii S.A., Raport Miesięczny, Warszawa 2012, s. 1.

25 S. van Dyken, B. H. Bakken, Skjelbred H. I., Linear mixed - integer models for biomass supply chains with transport, storage and processing, "Energy" 2010, no. 35, s. 1338-1350.

${ }^{26}$ G. Jastrzębska, Odnawialne źródła energii i pojazdy proekologiczne, Wydawnictwo Naukowo-Techniczne, Warszawa 2007, s. 57, 58. 
solid energy carriers (chips, pellets, briquettes), liquid energy carriers (ethanol, methanol) as well as gas energy carriers (woodgas, methane).

In Europe, notes the increased interest in biogas plants. Germany is a leading country where there are about 5,000 active biogas plant. The main energy raw material is corn. While livestock manure are supplement to energy production. They facilitate the decomposition of substrates. The European Union encourages to use of waste agricultural to energy production. In addition, the biogas plants can play a significant role in the sustainable rural development due to the decentralized nature, as well as enable the development of non-agricultural employment in rural areas and stimulating economic development in the region ${ }^{27}$. In the literature is many studies on the use of energy crops. Intentional cultivation, i.e. to intend for the energy production, are the risks connected with the possibility of crowding out the food production. There is concern that with the using appropriate support agricultural policy instruments may adversely affect food security.

Biomass can be an important source of energy production to take into consideration the limited resources of coal and other conventional energy carriers (oil and gas). In addition, increased demand for renewable energy sources is conditioned by the need to reduce greenhouse gas emissions. Moreover, world population increase that generates GDP growth, it is expected to increase demand for food, including highly processed products, which require more energy to production. A various possibilities for the use of biomass enable transformation traditional agricultural production (food production) to obtain the real energy resources $^{28}$. The possibility of generate energy from renewable sources increases the competition between the agricultural and the energy sectors, which is result from a similar demand for natural resources. Growing legal requirements for the technical and biological food production is a huge problem for some developing countries $^{29}$. It is necessary to integrated approach to the use and management of agricultural space.

The use of agricultural space for energy production incline to speculation on the food market. Observed the increase food prices in the world. In March 2011 , food prices increased on average by $2.2 \%$ compared with February - the price of sugar increased by $39.4 \%$, flour by $4.9 \%$, bread by $2.6 \%$, dairy products by $0.6 \%$, vegetable fats and butter by $1.7 \%$. Analyzing the interval from April 2010 to March 2011, food prices in Poland rose by 7.3\%, in the United States by about $2.8 \%$, in the European Union average of 3.3\%. The highest increase food

${ }^{27}$ A. Kupczyk, A. Wójcik, M. Majkowska, Wybrane problemy rozwoju sektora biogazu rolniczego w Polsce, [w:] F. Krawiec (red.), Odnawialne źródta energii w świetle globalnego kryzysu energetycznego. Wybrane problemy, Difin, Warszawa 2010, s. 77-87.

${ }_{28}$ A. Roszkowski, Bioenergia - pola i lasy zastapia węgiel, ropę i gaz?, „Inżynieria Rolnicza” 2009, no. 1(110), s. 243, 244.

${ }^{29}$ BEFS, Bioenergy and Food Security. The BEFS Analytical Framework, FAO, Rome 2010, s. $3-10$. 
prices was recorded in Poland, Slovakia, Hungary, Romania, Bulgaria, Lithuania, Latvia, Estonia. The lowest increase this ratio has been shown in Norway, Sweden, Spain, France, Belgium and Switzerland [http://epp.eurostat.ec.europa. eu]. The harvest all types of grain in the world gradually increased to 2008 and amounted to 2520700 thousand tons while fertilizer consumed per 1 ha of agricultural land. In contrast, the total harvest of grain in the world in 2009 declined by 31398 thousand tons compared to 2008. Taking into consideration external shocks (i.e. natural disasters such as tornadoes in the United States, the tsunami in Japan) can be estimated that the grain harvest may further decline with further increase food prices. Crop production for energy purposes requires action for achieving energy efficiency, while in the crop production for food purposes - achievement high quality food. There is a fear soil over-exploitation in the case of use conventional methods for energy purposes. On the other hand, according to the concept of sustainable agriculture is required use the agriculture space to crop production for energy purposes without interference in the crop production for food purposes, taking the fallow land into consideration. In recent years there has been an increase the prices of all cereals in Poland - the price of decitonne wheat grain increased by nearly 50\% in February 2011 compared with 2009, and the price of rye approximately $40 \%$, barley about $53 \%$, oats and mix cereal by $41 \%$, triticale by $46 \%$, maize by $50 \%$. In 2012 , agricultural product prices increased on average $4.2 \%$ compared with the previous year. In 2013 there was a further increase prices of the agricultural products.

Topicality issues result from the need to implement EU energy and climate policy by the member states, and that take into consideration of the increasing role of renewable energy sources. In April 2013 the European Parliament in the project "Resolution on microgeneration - small-scale electricity and heat generation" stated i.e., the need to support action to enable the development of local renewable energy cooperatives/association and to engage of community. The guidelines aim to support the internal energy market, to enable the member states to implementation the energy package and climate protection package in 2030 and to ensure energy security in the long run.

Inappropriate use the economic instruments force to support the EU climate and energy policy have negative influence to use biomass as an energy source. Increase imports of biomass from developing countries in order to realize the objectives of climate package often is destabilized, not balanced on the EU world economy. In the report "The Social Dimension of EU Biofuel Policy. Ecologic Briefs" (2012) identified many negative social factors as a consequence of biofuel policies. The main are: rising food prices, non-compliance with labor law, child labor on the energy plantations in low-developed countries, the sale of lands transnational companies, increase water consumption to production.

According to the forecasts of the Ministry of Economy, the economic potential of energy crops will reach 250.3 PJ in 2020. While the demand for biomass will 
be 299 PJ in 2020. According to forecasts energy prices could rise twice ${ }^{30}$. In 2012 was used 467.4 PJ of heat and 525.1 PJ of electricity ${ }^{31}$. The share of renewables in primary energy production was only $11.7 \%$ in 2012 . Poland is obliged to achieve $15 \%$ of energy from renewable sources in final energy consumption in 2020 . The difference between the primary and final energy is that the primary energy is included in the original carriers obtained directly from the environment. Whereas, the final energy is converted primary energy taking into consideration the efficiency of the processes of its processing. Therefore, it seems that the realization of Polish commitments will be difficult to achieve. One of the instruments to support the development of renewable energy are certificate of origin, the so-called green certificates. The problem is that the market is unstable. This is confirmed by a large drop price of green certificates in December 2012. The result was moved back power plants from co-firing of biomass with coal.

There is an observable trend to increase primary energy consumption in Poland. In 2012, the total stood at 4,443 PJ. The average energy consumption per capita was 114.4 GJ.

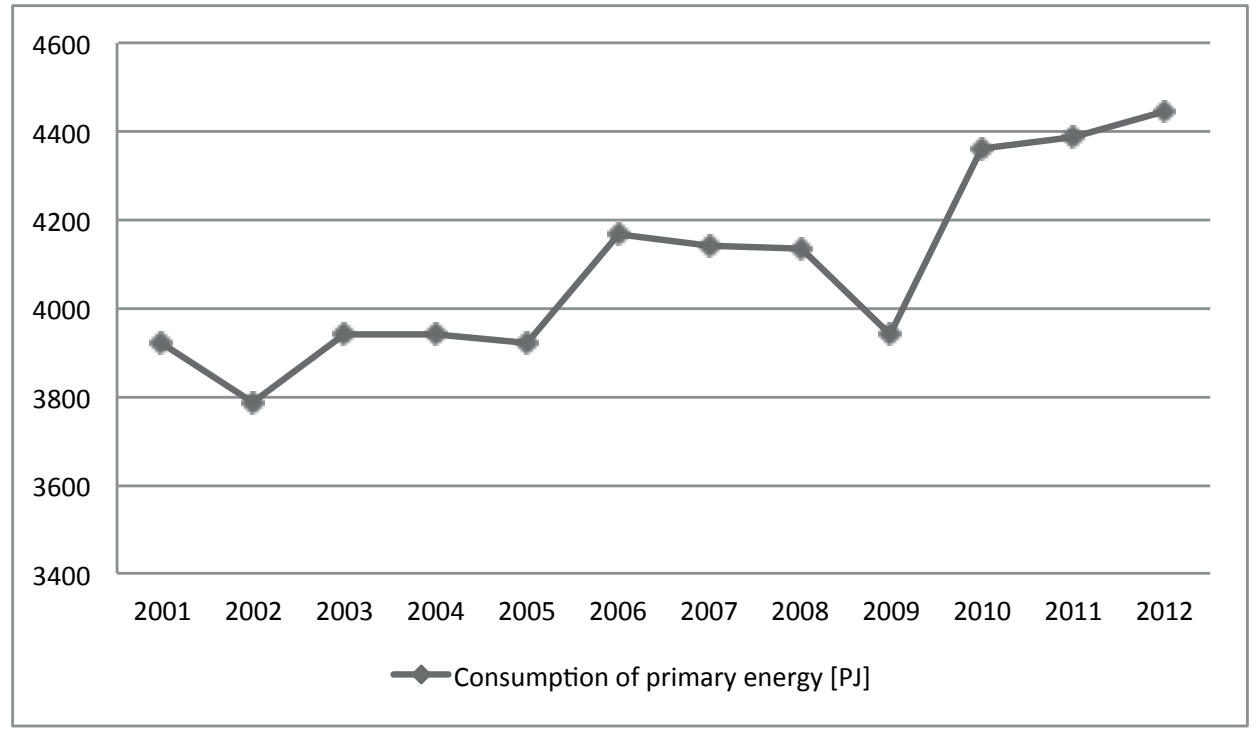

Figure 3. Consumption of primary energy in Poland in 2001-2012

Source: own study based on GUS (Central Statistical Office), Gospodarka paliwowo-energetyczna w latach 2010, 2011, Warszawa 2012, s. 52; GUS, Gospodarka paliwowo-energetyczna w latach 2011, 2012, Warszawa 2013, s. 52.

${ }^{30}$ Ministerstwo Gospodarki, Prognoza zapotrzebowania na paliwa i energię do 2030 roku, Warszawa 2009.

${ }^{31}$ GUS (Central Statistical Office), Zużycie paliw i nośników energii 2012 r., Warszawa 2013. 
About $13 \%$ of the energy produced in the world comes from renewable resources $^{32}$. In Poland, the share of renewable energy in the total energy production in the years $2007-2010$ increased from $6.69 \%$ to $10.16 \%$. Electricity production from renewable resources in Poland in 2012 was $16,879 \mathrm{GWh}$. The structure of electricity production from renewable energy resources is presented in figure 4 . Co-incineration of biomass and coal has the largest share. This method is controversial as to its reasonability its positive effect on reducing the emissions. However, the factors justifying the use of this method are: the lack of continuous supply of good quality biomass, lack of properly functioning local biomass markets, and the lack of implementation of appropriate technology in large power plants and co-generating power plants.

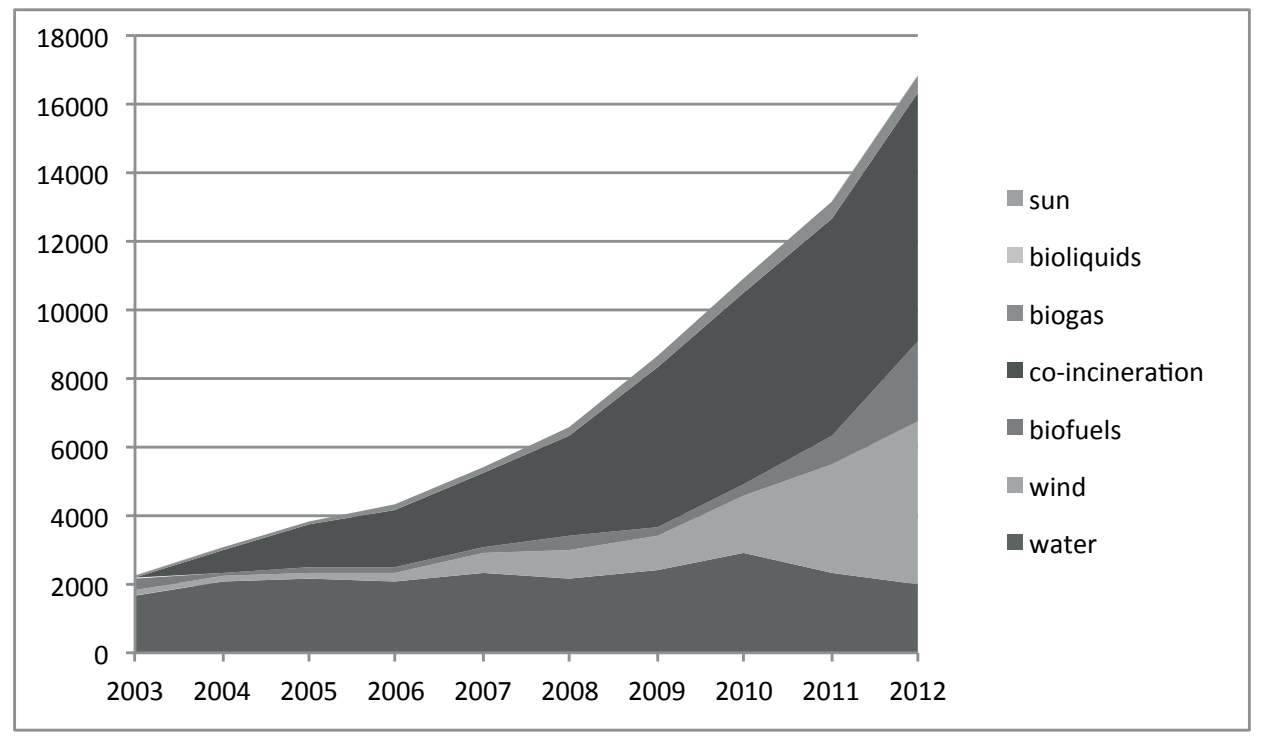

Figure 4. Production of electric power from renewable resources in the years 2003-2012 [GWh]

Source: Energy Regulatory Office (Urzad Regulacji Energetyki), data from the Polish Power Exchange (Towarowa Giełda Energii) for 2010; GUS, Energia ze źródet odnawialnych w 2012 r., Warszawa 2013, s. 57.

Heat production from renewable resources in Poland in 2012 was 19,548 TJ. The structure of heat production from renewable energy resources is presented in figure 6 .

${ }^{32}$ IEA Statistics, Renewables information, OECD/IEA 2012. 


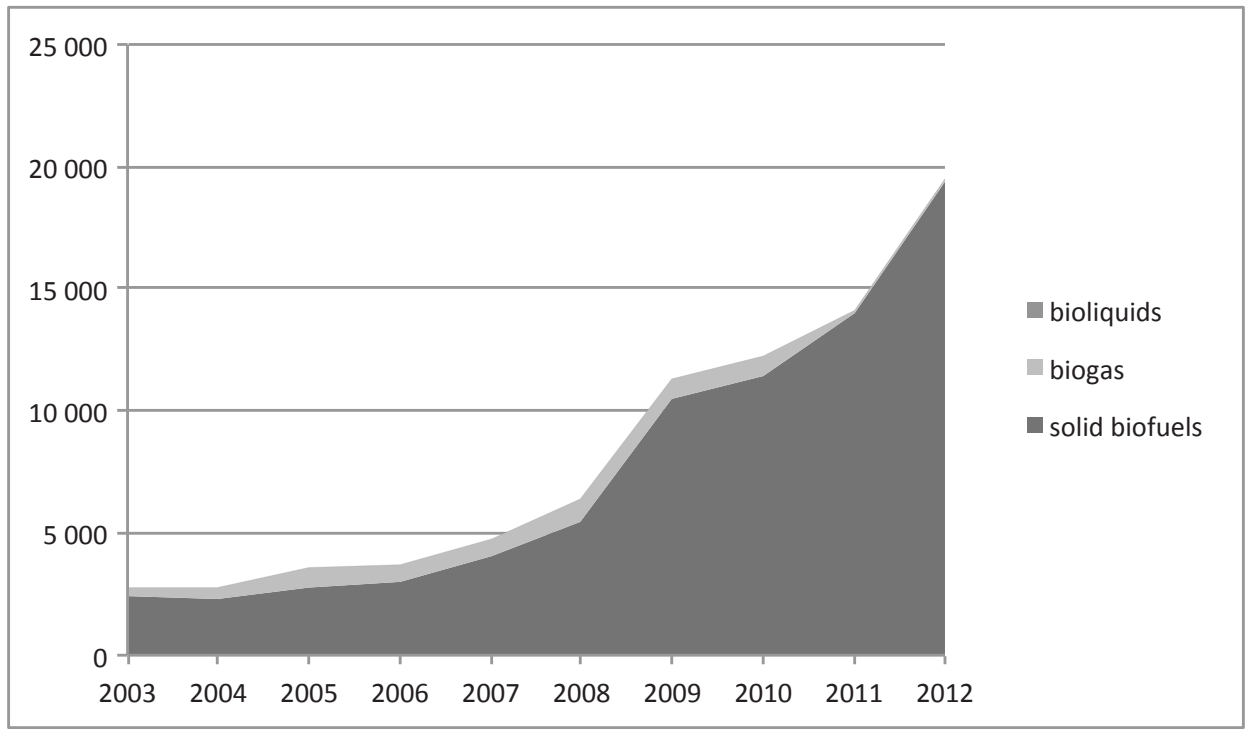

Figure 5. Production of heat from renewable resources in the years 2003-2012 [TJ]

Source: own study based on CSO (GUS), Energia ze źródeł odnawialnych w 2012 r., Warszawa 2013, s. 63 .

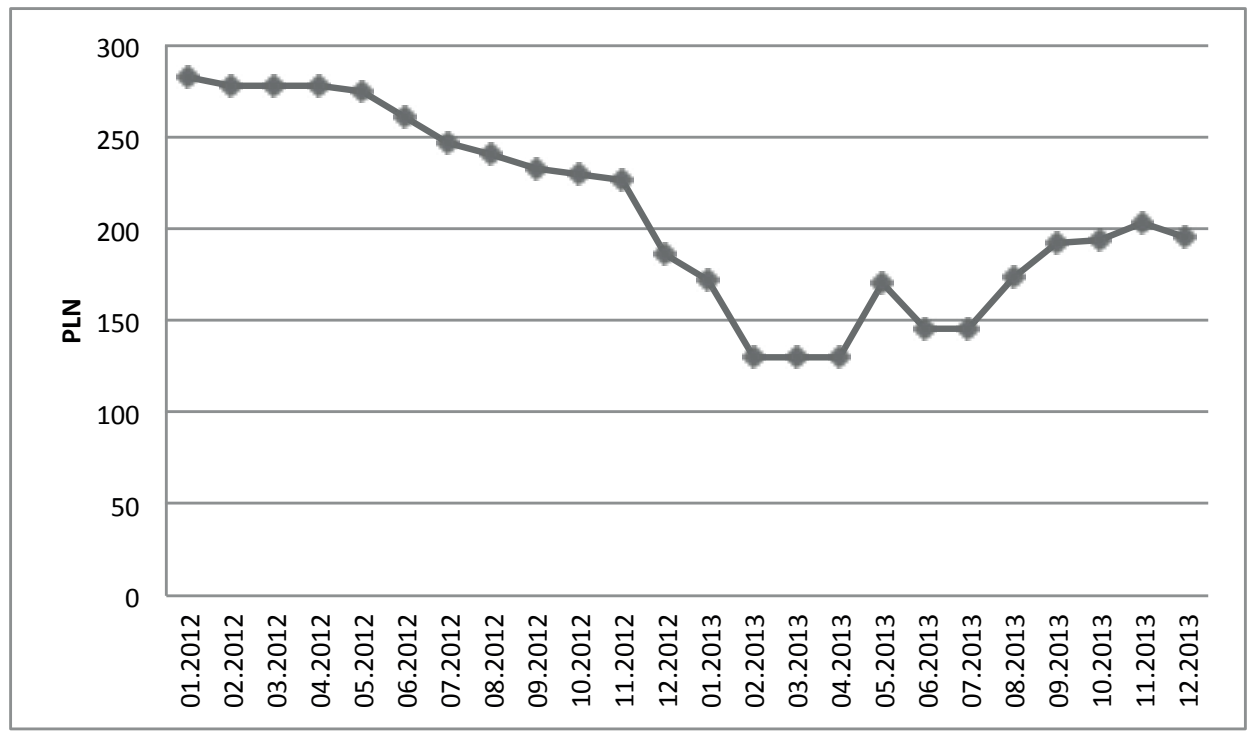

Figure 6. Average price of green certificates

Source: own study based on data from the Polish Power Exchange (Towarowa Gietda Energii), www.tge.pl (access 23.05.2014.) 
We can make the following thesis: implementation of Polish commitments regarding to energy - climate package (" $3 \times 20 \%$ ") is dependent on the further development of co-firing. The last two years have shown a peculiar instability of the energy sector and the high risk of achieving the indicative targets by Poland. It seems that there is a need for a green revolution in the energy sector. One of the conditions for the development of renewable energy is achieved the following aim: energy from renewable sources to be cheaper than energy from coal. To this end, the EU has introduced economic instruments such as: the emissions trading system and green certificates.

In Poland, support for development of energy market from renewable sources is not very effective. The RES Act was adopted April 8, 2014 -after a long waiting period. There are concerns that hopes support for prosumers disappeared.

Green certificates market crisis has had a negative impact on biomass producers. After the experience of the end of 2012, a further development of the agricultural biomass seems to be difficult. This paper is a kind of attempt to stimulate discussion on the economic aspects of the development of the agricultural biomass. It should be emphasized that estimates presented in the paper does not include the additional cost i.e. transport of biomass to the processing location, the energy production, commissions. Reflections on economic potential are strictly theoretical. The energy price from biomass is dependent on many factors, i.e. the energy price from conventional carriers, the certificates of origin prices, the emission allowances prices, cost of agricultural production, agricultural policy instruments. These issues require extensive research and analysis. In the literature, one of the barriers to growth in the use of agricultural biomass for energy purposes is the lack of well-functioning local biomass markets. It is absurd to import the biomass from abroad, while have a high potential in the country.

\section{Bibliography}

Baran D., Kwaśniewski D., Mudryk K., Wybrane właściwości fizyczne trzyletniej wierzby energetycznej, „Inżynieria Rolnicza” 2007, nr 8(96).

BEFS, Bioenergy and Food Security. The BEFS Analytical Framework, FAO, Rome 2010.

Budzyński W., Bielski S., Surowce energetyczne pochodzenia rolniczego. Cz. II: Biomasa jako paliwo state (artykut przegladowy), „Acta Sci. Pol. Agricultura” 2004, nr 3(2).

Chołuj D., Podlaski S., Wiśniewski G., Szmalec J., Kompleksowa ocena biologicznej przydatności 7 gatunków roślin wykorzystywanych na cele energetyczne, [w:] Harasim A. (red.), Uprawa roślin energetycznych a wykorzystanie rolniczej przestrzeni produkcyjnej w Polsce, „Studia i Raporty" 2008, z. 11, Instytut Uprawy, Nawożenia i Gleboznawstwa PIB, Puławy.

Dyken S. van, Bakken B. H., Skjelbred H. I., Linear mixed - integer models for biomass supply chains with transport, storage and processing, "Energy" 2010, no. 35.

Filipiak K., Syntetyczny wskaźnik żyzności gleby, [w:] Fotyma M. (red.), Nawozy i nawożenie, Polskie Towarzystwo Nawozowe, IUNG, Puławy 2010. 
Grzesik M., Janas R., Romanowska-Duda Z., Stymulacja wzrostu i procesów metabolicznych ślazowca pensylwańskiego (Sida hermaphrodita L. Rusby) za pomoca hydrokondycjonowania nasion, „Problemy Inżynierii Rolniczej” 2011, nr 4.

GUS (Central Statistical Office), Gospodarka paliwowo-energetyczna w latach 2010, 2011, Warszawa 2012.

GUS (Central Statistical Office), Zużycie paliw i nośników energii 2012 r., Warszawa 2013.

GUS, Energia ze źródet odnawialnych w 2012 r., Warszawa 2013.

GUS, Gospodarka paliwowo-energetyczna w latach 2011, 2012, Warszawa 2013.

GUS, Rocznik statystyczny rolnictwa 2010, Zakład Wydawnictw Statystycznych, Warszawa 2011.

Havlíčková K., Weger J., Knápek J., Modeling of biomass prices for bio-energy market in the Czech Republic, "Stimulation Modelling Practice and Theory" 2011, no. 19.

IEA Statistics, Renewables information, OECD/IEA 2012.

Igras J., Lipiński W., Ocena wybranych elementów stanu żyzności gleby i jakości płytkich wód gruntowych na tle intensywności produkcji roślinnej w ujęciu regionalnym, „Pamiętnik Puławski” 2006, z. 142.

Igras J., Lipiński W., Regionalne zróżnicowanie stanu agrochemicznego gleb w Polsce, [w:] Harasim A. (red.), Regionalne zróżnicowanie produkcji rolniczej w Polsce, „Raporty PIB” 3, z. 3, Instytut Upraw, Nawożenia i Gleboznawstwa, Państwowy Instytut Badawczy, Puławy 2006.

IUNG-PIB Puławy, [w:] Skrónicki H. (red.), Skrócone normatywy produkcji rolnej, Wydawnictwo Ministerstwa Rolnictwa i Rozwoju Wsi, Radom 2010.

Jastrzębska G., Odnawialne źródła energii i pojazdy proekologiczne, Wydawnictwo Naukowo-Techniczne, Warszawa 2007.

Kolowca J., Wróbel M., Wpływ wilgotności na właściwości reologiczne rozdrobnionej trawy energetycznej Miscanthus Giganteus, „Inżynieria Rolnicza” 2010, nr 4(122).

Komisja Europejska, Dyrekcja Generalna ds. Polityki Regionalnej, Przewodnik do analizy kosztów $i$ korzyści projektów inwestycyjnych. Fundusze strukturalne, Fundusz Spójności oraz Instrument Przedakcesyjny, Final Report 2008.

Krasowicz S., Oleszek W., Horabik J., Dębicki R., Jankowiak J., Stuczyński T., Jadczyszyn J., Racjonalne gospodarowanie środowiskiem glebowym Polski, „Polish Journal of Agronomy” 2011, no. 7.

Kundzewicz Z.W., Zalewski M., Kędziora A., Pierzgalski E., Zagrożenia związane z woda, „Nauka” 2010, no. 4 .

Kupczyk A., Wójcik A., Majkowska M., Wybrane problemy rozwoju sektora biogazu rolniczego $w$ Polsce, [w:] F. Krawiec (red.), Odnawialne źródła energii w świetle globalnego kryzysu energetycznego. Wybrane problemy, Difin, Warszawa 2010.

Kuś J., Faber A., Stasiak M., Kawalec A., Plonowanie wybranych gatunków roślin uprawianych na cele energetyczne na różnych glebach, „Problemy Inżynierii Rolniczej” 2008, nr 1.

Kwaśniewski D., Mudryk K., Wróbel M., Zbiór wierzby energetycznej z użyciem piły łańcuchowej (Harvesting osier with a chainsaw), „Inżynieria Rolnicza” 2006, nr 13.

Ligus M., Efektywność inwestycji w odnawialne źródła energii. Analiza kosztów i korzyści, Wydawca CeDeWu Sp. z o.o., Warszawa 2012.

Lisowski A. (red.), Technologie zbioru roślin energetycznych, Wydawnictwo SGGW, Warszawa 2010.

Matyka M., Kuś J., Plonowanie i cechy biometryczne wybranych genotypów miskanta, „Problemy Inżynierii Rolniczej” 2011, nr 2.

Ministerstwo Gospodarki, Prognoza zapotrzebowania na paliwa i energię do 2030 roku, Warszawa 2009.

Piskier T., Potencjat energetyczny topinamburu, „Problemy Inżynierii Rolniczej” 2009, nr 1. 
Roszkowski A., Bioenergia - pola i lasy zastapia węgiel, ropę i gaz?, „Inżynieria Rolnicza” 2009, nr 1(110).

Towarowa Giełda Energii S.A., Raport Miesięczny, Warszawa 2012.

Urząd Regulacji Energetyki, Departament Taryf, Taryfy OSD na rok 2012 (dotyczy OSD, którzy dokonali z dniem 1 lipca 2007 r. rozdzielenia działalności), Warszawa, listopad 2011.

Urząd Statystyczny w Łodzi, Rolnictwo w województwie łódzkim w 2011 r., Informacje i Opracowania Statystyczne, Łódź 2012.

Zawadzka A., Imbierowicz M., Rośliny energetyczne oraz technologie i urzadzenia dla przetwórni biomasy, [w:] Kochańska E. (red.), Inwestowanie w energetykę odnawialną. Aspekty ekologiczne, technologie, finansowanie i benchmarking, Stowarzyszenie Doradców Gospodarczych Pro-Akademia, Łódź 2010.

\begin{abstract}
This paper presents a model of uncultivated agricultural land under appropriately selected energy crops. The main goal of this work is to estimate energy production potential of fallow soil and fallow land in the Łódź Province on the basis of selected energy crops and to calculate the minimum price of energy crops. The Net Present Value (NPV) method was used to calculate the minimum price, and the literature studies to build the model using. The following analysis verifies the main research hypothesis, i.e., that the Łódź Province has a theoretical and economical energy-production potential of biomass in the areas of fallow soil and fallow land. The hypothesis was verified positively. The study shows that practicing energy willow achieved the lowest price for generation of $1 \mathrm{MWh}$.
\end{abstract}

Keywords: biomass, energy crops, the minimum price, energy and climate policy

JEL classification: Q1, Q4, Q5 